\title{
Kerkwees in veranderde tye: Die Nederduitsch Hervormde Kerk teen die agtergrond van verskuiwende paradigmas
}

\author{
D J C van Wyk (jr) \\ Tydelik deeltydse dosent: \\ Departement Nuwe-Testamentiese Wetenskap (Afd A) \\ Universiteit van Pretoria
}

\begin{abstract}
Being church in times of change: The Nederduitsch Hervormde Kerk against the background of shifting paradigms

Against the background of the turn of the millenium, humanity finds itself in a stage of transition. Not only are the church and theology fully aware of this, but they are directly affected. This study is an endeavour to assess where the church, theology and believing community in South Africa, and particularly the Nederduitsch Hervormde Kerk, finds themselves against the background of a world-wide shift in paradigms. The study concludes with a few remarks regarding statements, positive and negative, which are being voiced by leaders in the church and by theologians within the Nederduitsch Hervormde Kerk. These remarks focus on how the Nederduitsch Hervormde Kerk should meet the approaching millenium. It is obvious that the church is nearing a very exiting, but crucial time in its vocation as church.
\end{abstract}

Uiteindelik is dit nie die kerk wat sending doen en onderneem nie. Dit is die Missio Dei wat die kerk konstitueer.

(Bosch 1991:519 [my vertaling])

Die kerk is miskien dan nie so glansryk, so indrukwekkend nie. Maar [die kerk] bly in die hande van God.

O Noordmans (aangehaal deur Oberholzer 1993:873)

\footnotetext{
* Die konsep van hierdie artikel het as gespreksdokument voor die Ringsraad Predikantevergadering van die Ring van Zuurfontein gedien op 17 September 1998. Ds Van Wyk is predikant van die Nederduitsch Hervormde Gemeente Zuurfontein, Kemptonpark.
} 


\section{INLEIDING}

Daar vind tans dramatiese verskuiwings en veranderings in die wêreld en hier te lande plaas (Dreyer 1998:289). 'Daar heers storm en drang soos nog nooit in die lewe van hierdie land [Suid-Afrika - Van Wyk (jr)], en al sy mense, hierdie volk [die Afrikanervolk - Van Wyk (jr)] en hierdie kerk [die Nederduitsch Hervormde Kerk - Van Wyk (jr)] nie' (Van Wyk 1998c:4). Vir die hele mensdom lyk die lewe op aarde by die aanbreek van die een en twintigste eeu somber en onveilig (Van Wyk 1998c:6). Volgens Hans Küng (1992:14) ervaar mense die teenswoordige tyd as 'n tyd van algemene gebrek aan oriëntasie en dikwels betekenisloosheid (meaninglessness). Hierdie era van onsekerheid en betekenisloosheid raak die geloof van mense en die totale spektrum van die kerklike bediening. Dit lyk asof dit ' $n$ tyd is waarin massale geloofsafvalligheid opnuut dreig. Mense soek na vaste punte om staande te bly en die oorgange na nuwe paradigmas van bestaan, lewe en kerkwees te verwerk.

Dit is vir die kerk belangrik om die huidige situasie raak te probeer lees en op grond daarvan die toekoms reg te antisipeer. Dit is nooit 'n maklike taak om die huidige tyd binne perspektief te verstaan, te beoordeel en leiding te gee oor hoe om die toekoms tegemoet te gaan nie. Die kerk word voortdurend gekonfronteer met die tydsgees waarin die mensdom verkeer en aan wie die kerk die evangelie moet bring. In dié opsig leef die kerk in die spanning om die tydsgees akkuraat te peil en die evangelie binne dié tydsgees raak te verkondig maar om nie daardeur op sleeptou geneem en meegesleur te word nie (kyk Pont 1994:5). Word die kerk deur die tydsgees op sleeptou geneem, is die kerk se roeping reeds versaak en het die kerk niks meer om vir die mens van die teenswoordige tyd te sê nie. Die teologie en die kerk kan daarom nie anders as om te poog om die huidige tyd te probeer verstaan en op grond daarvan vanuit die Woord leiding te gee nie.

In die kerk se besinning oor wat die taak en die opdrag is wat uitgevoer moet word, speel denkparadigmas 'n belangrike rol. Die gebruik van die woord paradigma het inderdaad 'n modewoord geword wat los en vas gebruik word (kyk Küng 1988:171173). In die skopus van hierdie studie kan dit egter gesien word as die totaliteit van denke, persepsies en waardes binne die gemeenskap/pe wat lei tot 'n spesifieke visie op die werklikheid (kyk Van Aarde 1995a:15). Denkparadigmas bepaal in 'n sekere sin die mens se ontvanklikheid vir die verkondiging en bediening van die kerk. Denkparadigmas bepaal in ' $n$ sekere ander sin die teologie van die kerk en daarmee saam die inhoud en vorm van die kerklike verkondiging en bediening.

Die besinning oor paradigmas en hulle verskuiwings en die relevansie daarvan vir die uitvoering van die kerk se opdrag, kan niks en niemand anders se taak wees as dié van die teologie nie. Immers, wanneer die kerk besin oor die kerk se roeping in die wêreld en oor die uitvoer van die opdrag wat die kerk opgelê is, dan teologiseer die kerk. Teologie is (baie eenvoudig gestel), 'die wetenskaplike besinning oor God in 
verhouding tot die mens' (Van Aarde 1995a:15; kyk ook Dreyer 1994:5). Karl Barth het die taak van die teologie nog veel nouer gesien. Teen die agtergrond van die liberale teologie van die negentiende eeu het Barth die nood van die prediking raakgesien. Die liberale teologie het tot gevolg gehad dat die kerk nie meer in die prediking vir die mens in nood wat in die tydsgees vasgevang sit, iets te sê gehad het nie. Daarom was dit vir Barth baie belangrik dat die teologie in diens van die prediking moes staan ten einde die taak van die kerk teenoor die ontredderde mensdom gestalte te laat vind ${ }^{1}$ (kyk ook Pont 1994:5).

Hierdie studie poog om te peil waar die kerk, die teologie en die geloofsgemeenskap in Suid-Afrika hulleself tans teen die agtergrond van verskuiwende paradigmas wêreldwyd bevind. Die studie sluit af met enkele kritiese opmerkings ten opsigte van wat kerkleiers en teoloẻ binne die Nederduitsch Hervormde Kerk sề oor waar die Hervormde Kerk staan en hoe die Hervormde Kerk die volgende millenium tegemoet behoort te gaan. Daarmee val dit op dat die kerk 'n baie opwindende tyd van kerkwees tegemoet gaan. Die kerk sal dinamies moet kerk wees en teologiseer om met die oorgange na nuwe eras tred te hou, maar sonder om deur die tydsgees meegesleur te word. Tog laat Dreyer (1996:180) hieroor ook 'n waarskuwende woord hoor:

Om die nuwe situasie [veral met betrekking tot kerk wees in die nuwe Suid-Afrika - Van Wyk (jr)] as 'n uitdaging te sien, is egter vir die meeste Afrikaners en lidmate van die Hervormde Kerk nie so maklik en vanselfsprekend nie. Die kerk kan homself maklik van sy lidmate vervreem en predikante kan hulle geloofwaardigheid inboet deur, met verbygaan van mense se vrese en pyn, gewoon na die nuwe situasie as 'n uitdaging te verwys.

\section{VERSKUIWENDE PARADIGMAS}

\subsection{Agtergrond}

By die nagaan van paradigmaverskuiwings, blyk dit dat sodanige verskuiwings volgens 'n bepaalde patroon verloop (kyk Küng 1988:135vv; Van Aarde 1995a:16-17):

* Die fisika lei gewoonlik 'n paradigmaverskuiwing in wanneer 'n nuwe wêreldbeeld of kosmologie die mens se begrip van die werklikheid verander;

* Die filosofie volg die fisika wanneer daar nagedink word oor die mens se plek binne die nuwe kosmologie wat die fisika daargestel het; 
* Die teologie volg die fisika en die filosofie wanneer die verhouding tussen God en mens binne die nuwe wêreldbeeld bedink word.

Met hierdie patroon word allermins gesê dat die begin en einde van paradigmas eksak, simplisties en volgens jaartalle aangedui kan word. Paradigmas volg mekaar oor lang periodes op en dit is nooit presies uit te maak wanneer ' $n$ bepaalde paradigma opgehou het 'n nuwe reeds begin het nie (kyk Van Aarde 1995a:15-19). Tog toon 'n terugblik op die laaste drie paradigmas in die geskiedenis van die mensdom hierdie bepaalde patroon. Elke paradigmaverskuiwing het die einde van een wêreld en die geboorte van ' $n$ nuwe aangedui. . Dit het telkens daarmee gepaard gegaan dat baie dinge wat mense vroeër gedink en geglo het, hergedefinieer en nuut of selfs anders gesê moes word.

Daar is reeds deur navorsers (kyk Bosch 1991; Küng 1988; Van Aarde 1995a) op verskeie paradigmaverskuiwings gewys waarby ons in hierdie studie kan verbygaan, terwyl ons ter wille van illustrasie en ter wille van ons tema op die laaste drie konsentreer.

\subsection{Die premoderne paradigma (Middeleeuse Rooms-Katolieke paradigma - H Küng, D Bosch, T Kuhn)}

Die premoderne paradigma was die era wat ook bekend staan as die middeleeue (ongeveer 500-1500). Gedurende diê tyd het die Rooms-Katolieke Kerk alles beheer en vir mense voorgeskryf: hoe die wêreld lyk, hoe die mens moet dink, hoe die mens oor God moet dink. Dit het tot 'n groot mate beteken dat mense op die grondvlak van die samelewing nie self gedink het oor singewing in die lewe nie. Die wetenskap is verbied om resultate ten opsigte van die werklikheid bekend te maak wat strydig is met dit wat die kerk geleer en voorgeskryf het. In dié opsig is die wetenskap en die filosofie, en daarmee saam die ganse mensdom, deur die kerk geïnhibeer tot dit wat die kerk voorgeskryf het.

\subsection{Die moderne paradigma}

Aan die einde van die middeleeue kom die mens in verset teen die dominansie van die kerk. Die fisika lei hierdie verset in met die Kopernikaanse rewolusie. Op die gebied van die kosmologie het die groot verskuiwing in die sestiende en sewentiende eeu gekom toe die Ptolemeuse kosmologiese model, waarvolgens die aarde in die middelpunt gestaan het en al die ander hemelliggame in sirkels daarrondom beweeg het, vervang is deur die insigte van eers Kopernikus en daarna Kepler en Galilei. Die nuwe kosmolo- 
gie wat nou na vore getree het, is dié van die son in die middelpunt en die ander hemelliggame wat rondom die son beweeg. Heel gou is ook hierdie siening verder verander deur die ontdekkings van ander sonnestelsels en sterrestelsels. Ons eie sonnestelsel is nie die middelpunt van die heelal nie, maar raak verdwerg deur honderd duisende ander sterre-stelsels (kyk Adam 1995:12). Hierdie kosmologie is gaandeweg in wetmatighede vasgelê deur die teorieê van onder andere Newton en Einstein. Gedurende die negentiende en die eerste helfte van die twintigste eeu is hierdie wêreldbeeld gevestig as synde 'n heelal wat kousaal-meganies volgens vasgestelde natuurwette funksioneer. Veral die gravitasiewette van Newton en die algemene relatiwiteitsteorie van Einstein wat die kosmos op makrovlak beskryf, het die optimisme verhoog dat die mens eventueel in beheer van die kosmos sal kan wees, omdat die mens die werking van die kosmos volkome begryp. Dié naturwette kan immers, so is gemeen, sowel die ontstaan van die heelal as die ontwikkeling en verloop van die heelal beskryf (en waarskynlik ook die afloop daarvan! [kyk Hawking 1988:5vv]).

Die filosofie het die fisika se deurbreking van die kerklike gesag onmiddellik opgevolg met 'n vryheid van denksisteme en filosofie. Hiervan was die filosofie van Descartes van die eerstes wat die onafhanklikheid van die individuele menslike denke op die voorgrond gestel het. Die moderne filosofie het uitgeloop op die Aufklärung. Die moderne mens en dié se rasionaliteit staan voorop en is die eerste en laaste maatstaf vir die werklikheid en die verstaan daarvan. Die middeleeuse denke, wat onder die totale invloed van die kerk was en gekenmerk is deur die onderskeid tussen die transendente en die immanente (met al die klem op die transendente), is deur die Renaissance en die opkoms van die moderne era deur die dualistiese subjek-objek denke vervang. In hierdie paradigma is veral gefokus op die subjek. Die subjek is beskou as die onafhanklike, rasioneel denkende subjek. Die klem is derhalwe gelê op mense as outonome, rasionele wesens met onbeperkte vermoëns. Hierdie beskouing oor die mens en die mens se verhouding tot die wêreld en die werklikheid, het die stimulus gegee vir die geweldige ontwikkeling op die gebiede van die wetenskap, sosiologie en tegnologie.

Die teologie het die fisika en die filosofie gevolg met 'n dogma-vrye en kerklikvrye en ongebonde ondersoek na die verhouding tussen God en mens. Hierdie vryheid is gebalanseerd deur die Reformatoriese teologie toegepas en verwoord. Die Bybel is beskou as die primêre gesag en bron om oor die verhouding tussen God en mens na te dink. Die Aufklarung het egter, ongebalanseerd in die uitwerking van die volle konsekwensies daarvan in die liberale teologie, daartoe gelei dat die mens en die instrumentele rede die finale maatstaf was vir die verstaan van God en die verhouding tussen God en mens. Dit het daartoe gelei dat die natuur van 'goddelike betowering' ontneem is (Van Aarde 1995a:23-24). Vir die liberale teologie het dit die volgende beteken: 
* Dit het meegebring dat die transendensie van God verloor is. Daar kom 'n algemene misnoee met en gebrek aan belangstelling in God en die transendente. Die mense wil hulle eie lewens beheer, met hulle verstand besluit wat reg en verkeerd is, en hulle eie heil uitwerk. Mense het hulle eie god geword. Dit het tot vandag toe verreikende gevolge vir die antropologie.

* Soteriologies het die konsep van sonde en 'n verlore mensdom nie meer saak gemaak nie. Die mens het nie 'n verlosser nodig nie. Met die rede en tegnologie werk mense hulle eie heil uit.

* Christologies is Christus ontmitologiseer en gestroop van die transendente (die maagdelike verwekking, die wonders, die opstanding, die Godheid van Jesus). Jesus is 'ontchristelik'. Hy was 'n gewone mens en sy waarde lê daarin dat Hy vir die mondige mens die voorbeeld gestel het van hoe om die lewe sinvol te lewe (kyk Van Aarde 1996:480).

Die aard van die moderne era is 'n verset teen die kerk. Moderne mense verset hulle teen enigiemand wat vir hulle wil voorskryf wat om te doen; daarom ook teen die kerk as die draer van die Goddelike woord wat 'n appel op mense se lewens maak. Waar daar wel in die geloof by die kerk gebly is, het dit vir baie begin opgaan in 'n tipe voorspoedsgeloof. Moderne mense wat rasioneel met die Bybel omgaan, werk vir hulleself 'n interpretasiemodel uit van: wanneer ek God dien, sal ek daarvoor iets terugkry. Daarom sal dit goed gaan met dié mens wat God dien. Wanneer dit nie goed gaan nie, word God daarvoor verwyt, of word die geloof en God vaarwel toegeroep. Die mens skuif in die plek van God in. Die mens, en nie meer God nie, ken die waarheid en lê die reëls vir die lewe neer. Dit beteken dat daar 'n uitermate optimistiese mensbeskouing is (kyk Adam 1995:1-2). Die mondige mens roem op die verstand, die tegnologie en die wetenskaplike vermoëns van die mens. Mense en die wêreld het God nie meer nodig nie. Hulle werk hulle eie heil uit.

\subsection{Die postmoderne paradigma}

Die fisika het die moderne gedetermineerde wêreldbeeld in duie laat stort met die teorieè yan die kwantummeganika oor die onvoorspelbaarheid van die mikrokosmos (Hawking 1988:53-62). Die teorie van kwantummeganika is gebaseer op die sogenoemde onsekerheidsbeginsel (uncertainty principle) wat Werner Heissenberg in 1926 geformuleer het. Dit beskryf die natuurwetmatighede op die mikrovlak van die kosmos. Volgens die vroeëre teoriee van Newton en Einstein kan die toekomstige posisies van objekte (bv hemelliggame) voorspel word deur hulle teoriee daarop toe te pas. Die on- 
sekerheidsbeginsel het egter uitgewys dat die toekomstige posisie van 'n partikel op mikrovlak nie bepaal kan word nie, aangesien 'n partikel 'n onwillekeurige sprong maak wat nie deur enige teorie voorspel kan word nie.

Hierdie onsekerheidsbeginsel het ingrypende implikasies ingehou vir die gedetermineerde wêreldbeeld van die moderne era. Hoe kan die kosmos op makrovlak kousaalmeganies volgens natuurwette voorspel word, as dit nie eers op die kleinse mikrovlak voorspelbaar is nie? Kwantummeganika postuleer nie 'n enkele uitkoms vir die onsekerheidsbeginsel nie, maar hou rekening met talle moontlike uitkomste. Met die verdere ontwikkelings van die fisika op die makrovlak van die kosmos word dit al meer en meer moontlik dat die teorie van kwantummeganika ook die kosmos op makrovlak ingrypend kan beinvloed.

Daar kom dus in die 'postmoderne' fisika 'n verset teen die determinisme van die moderne. Daarmee saam ook 'n pessimisme oor die mens se vermoëns om die kosmos met die mens se verstand en tegnologie te beheer. Alles raak relatief. Dit is nie so maklik om met sekerheid te onderskei tussen reg en verkeerd nie. Daar is verskillende moontlike uitkomste vir 'n bepaalde probleem. Die postmoderne filosofie kom in verset teen die mens en die mens se verstand en gewaande vermoëns. Dít het in die twintigste eeu gelei tot die grootste verwoesting van menselewens ooit in twee wêreldoorloë (kyk Van Wyk 1998b:21; Küng 1992:12). Sameloop en samevloeiings van verskillende sake speel 'n groter rol as wat gemeen is. Selfs volslae chaos as uitkoms op baie sake moet in aanmerking geneem word. Dit word toenemend duidelik dat die mense met hulle geweldige ontwikkeling juis daarmee vir hulleself groot probleme skep; probleme wat lei tot die vernietiging van die mens self en die vervreemding van die mens in die wêreld. Die moderne denke bied nie langer meer oplossings om aan al hierdie probleme aandag te gee nie.

Binne die postmoderne filosofie is gevestigde, konvensionele waardes uitgedien. Alles raak relatief, vervloei en sonder vaste bane en vastigheid. Die postmoderne mens is wars van alle absoluuthede (kyk Adam 1995:15). Dit lei tot 'n gebrek aan standvastigheid en tot identiteitskrisisse. Die enkeling soek na 'n groter geheel (holisme) waarbinne hy of sy weer identiteit kan vind. Daar is by die verwarde postmoderne mens 'n soeke na die transendente, na die goddelike, na die mistiese. Die rede daarvoor is die misnoeë met die moderne mens. Moderne mense het gedink hulle het God nie nodig nie; hulle kan hulleself red. Na twee wêreldoorloë en die grootste verwoesting van menselewens ooit, lê die mense se vertroue in hulleself aan skerwe. Daarom is daar 'n natuurlike teruggrype na die goddelike. As die mens nie kan nie, moet daar dalk tog 'n God weès wat kan help. Daar is opnuut 'n belangstelling in die mitologie en oosterse godsdienste. Wêreldwyd kom daar oplewings in die apokaliptiek na vore. 
Die postmoderne mens dink nie langer dogmaties nie, maar funksioneel. 'n Ding moet $\sin$ maak en bruikbaar wees, anders word dit verwerp. Dit geld ook die geloof en God. As dit nie funksionele waarde het nie, is dit irrelevant. Dit geld ook die prediking van die kerk. I W C Van Wyk (1996:501) verwoord dit soos volg:

Die dogmatiek (veral die kerklike dogmatiek) word vermy, aangesien 'n ander dogma, die binetariese dogma van aanvraag en aanbod met die aanloklike belofte van sukses daarby, hoogty vier. Daar word by die empirie begin, aangesien die hoofbelangstelling nie meer rondom die waarheid nie, maar rondom die 'sukses' sentreer. Dit gaan daarom vandag om dit wat 'tuiskom', omdat dit wat kan 'tuiskom' die norma normans van die preekleer geword het.

Die postmoderne teologie het positief gestalte gevind in die dialektiese teologie as verset teen die liberale teologie en as antwoord op die verwarde postmoderne mens sonder hoop (kyk Küng 1988:271vv). Die hoogbloei van die modernisme was die mens wat in die middelpunt gestaan het. Daarmee het die mens weggedoen met die transendensie van God en God en mens met mekaar vermeng. Hierteenoor het Karl Barth met sy teologie van die krisis die gansandersheid van God beklemtoon. God is God en God bly God. Die mens is mens en die mens bly mens. Daar is ' $n$ kwalitatief oneindige verskil tussen God en mens, tussen ewigheid en tyd. Die mens kan nooit oor God beskik of God deurvors nie. Daarom word die dialektiese teologie gekenmerk deur voorlopigheid en nederigheid by die mens. God maak Godself aan die mens bekend. Sonder dié bekendmaking van God kan die mens van God niks weet nie. Daar is geen pad van die mens af na God toe nie. God kan nie in mensewoorde en formulerings vasgevang word nie. Die dialektiese teologie se klem op die gansandersheid van God het die kerk en die Christendom gered van afgodsdiens.

Negatief het die postmoderne teologie uitgeloop op verskeie nuwe vorms van liberale teologie. Een godsdiens kan nie langer alleen op waarheid aanspraak maak nie (kyk Finesse 1998:8). Die godsdienste aanbid almal dieselfde God. Die waarheid is geheel vloeibaar. Die onvermoe om die waarheid finaal onder woorde te bring, hou verband met die postmoderne siening van taal. Taal is relatief. Dit is nooit absoluut akkuraat nie. Dit is onmoontlik om teologiese waarhede absoluut en finaal te omlyn. Alles is aanvaarbaar. Daar word gestrewe na 'n globale geheel waarin die enkeling nie misken word of hoef te verdwyn nie. Al wat verkeerd is, is as jy alleenaanspraak maak op die waarheid of op God of op wat ook al. Almal moet saam soek en saam verant- 
woordelikheid aanvaar vir die wêreld en die probleme van die mensdom. Dawid Bosch (in Van Wyk 1996:155) het in die verband verwys na die dilemma waarin die Christelike kerk en teologie ten opsigte van die sending in die postmoderne tyd verkeer: Al meer teoloë twyfel oor die sin daarvan om met die evangelie na die uiteindes van die aarde te gaan. Waarom, as al die mense in elk geval gered word? Daarom ook is die sendeling nie meer so 'n sentrale figuur nie, eerder iets van 'n verleentheid. Ten opsigte van die Christendom word daar al meermale gepraat van 'n post-kerklike Christendom (kyk onder andere Funk 1996). Mense het nie die kerk nodig om Christene te wees nie. Buitendien het die kerk in soveel opsigte geloofwaardigheid verloor, dat die mense nie kans sien om as deel van die kerk Christene te wees nie.

Daar is 'n algemene 'godsdienstige' soeke na spiritualiteit (vgl Dreyer 1998: $290 \mathrm{ev})$. Binne die postmoderne idioom het die begrip 'spiritualiteit' 'n interdissiplinêre, interdenominasionele en intergodsdienstige karakter. 'Religieusiteit, mistiek, askese, kom ver buite die grense van die Christendom voor' (Dreyer 1998:29ì). Die postmoderne teologie word gekenmerk deur die interdissipilinêre aard daarvan. Bybelwetenskaplikes maak vryelik gebruik van die insigte vanuit ander dissiplines soos die sosiologie, psigologie, antropologie, en dies meer (kyk Van Aarde 1998:32, 79, 84; Vorster 1988:31).

Die postmoderne mens en wêreld lei maklik tot nihilisme. Dit word bevestig deur die feit dat al die groot skemas van die Westerse wêreld verkrummel en in duie gestort het. Deel van die ineenstorting was ook die onkritiese toejuiging van elke vorm van verandering, vernuwing en bevryding van die sestiger- en sewentigerjare. Dit het gelei tot nihilisme, want die geloof om te glo wat jy wil, lei geleidelik tot geen geloof (Van Wyk 1996:155). Die nihilisme manifesteer veral op die morele gebied van die mensdom. 'n Geslag mense tree in die postmoderne era na vore wat by al die 'vryheid' en 'beskawing' innerlik en moreel voos en verrot is wanneer dit gemeet word aan egte Bybelse moraal. Die humanisme wat vir God geen plek het nie, het deur die twee wêreldoorloë heen, deur die uitwissing van 6 miljoen Jode heen, deur die gevolge van die atoombom heen, bewys dat die pad vanaf die mens sonder God na bestialiteit baie kort is (Küng 1992:12). In 'n verslag wat aan die einde van 1998 in Hamburg vrygestel is en wat gewapende konflik wêreldwyd aandui, blyk dit dat 'n wêreld van vrede en harmonie aan die einde vạn hierdie millenium 'n ydele droom sal bly. Wêreldwyd is daar konflikte en dreig daar meer konflikte tussen mense en nasies. Daar is dreigende corloë oor die hele vasteland van Afrika, voortslepende onrus in Asiē en die Midde Ooste en guerilla-bewegings in Latyns-Amerika (Beeld 1998:9).

Die mees kenmerkende van die volle uitwerking van die postmoderne era is die reaksie en verset teen die idealistiese mensheid en die feit dat die mens se vermoëns in 
die sentrum gekom het. Daar is 'n onbehae met die mens wat in die plek van God ingeskuif het. Daar kom 'n nuwe soeke na die goddelike en die transendente. Dit beteken egter nie dat die wêreld meer Christelik of kerklik georiënteerd raak nie.

\section{DIE SITUASIE IN SUID-AFRIKA EN DIE KERK IN DIE ALGEMEEN}

Die tradisionele kerkmens (veral die Afrikaner) het die negatiewe invloed van die Aufklarung tot onlangs toe vrygespring. Die Afrikaner was nie uitermate krities ingestel nie. Onder sterk invloed van die Reformasie en met ' $n$ tradisioneel gelowige volk kon die tradisionele Afrikaanse kerke in Suid-Afrika daarin slaag om met die konvensionele antwoorde die onkritiese kerkvolk na behore te bedien. 'n Deel van die Afrikaanse kerkyolk bevind hulleself steeds in hierdie 'premoderne' paradigma. Die tradisionele antwoorde is steeds die enigste moontlike antwoorde. Wat die kerk tradisioneel gesê het, kan steeds die enigste moontlike antwoorde wees. As sodanig is die premoderne mens wars van enige vorm van vernuwing of 'n kritiese kyk na die kerk, die teologie en die kerklike bediening.

Tog het daar by baie 'n merkbare verskuiwing plaasgevind. Die moderne sug van die mens na vryheid en onafhanklikheid tref baie van die tradisionele kerkmense (die Afrikaners) vandag met ontsettende felheid. Dit gaan na alle waarskynklikheid die kerk in die tyd wat kom, nog baie swaarder tref. Die moderne mens anvaar nie meer die gesag van die Skrif óf dié van die kerk nie. Hulle volg hulle eie koppe. Daar is by die meeste mense waarskynlik eerder ' $n$ verset tén die kerk en die transendente, as 'n eg postmoderne soeke na die goddelike (wat in ander eerste-wêreldlande wel sterk gebeur). Die verset teen die kerk en die Skrif bestaan daaruit dat die moderne mens self wil besluit wat aanvaarbaar is en wat nie. In die oorweging van sake laat dié mense hulle deur niks voorskryf nie. Daarom huiwer hulle ook nie om die kerk vaarwel toe te roep indien die kerk te voorskriftelik te werk gaan nie. Die moderne Afrikaner gaan toenemend rasioneel met die geloof om. Indien die geloof nog saakmaak, rasionaliseer hulle oor wat werklik vir hulle saakmaak en wat nie. Hulle laat hulle nie werklik deur die Skrif, deur God of die kerk voorskryf oor wat reg en verkeerd is nie. Alhoewel baie Afrikaners hulle dus binne die moderne paradigma bevind, word hulle met 'n postmoderne wêreld gekonfronteer.

Daar is egter ook duidelike tendense van die postmoderne wêreld wat alreeds neerslag vind in die denke van Afrikaners. Veral die jeug is waarskynlik reeds in 'n groot mate postmodern. In dié verband word meermale verwys na die sogenaamde generasie $\mathrm{X}$-kinders. Die ingesteldheid van die moderne en sekerlik die postmoderne wêreld het die sogenaamde generasie-X kinders tot gevolg. Botha (1998:28-29) beskryf iets van die generasie- $\mathrm{X}$ kinders: 
* Kinders het nie meer identiteit nie, want hulle kry dit nie by hulle ouers nie. Ouers se oggend en aandpraatjies is nie meer dieselfde nie. Wat hulle sê en wat hulle die kinders leer, is een ding, maar in die ouers se lewens sien die kinders 'n ander ding.

* Dan word kinders deel van die gesigslose massa. Hulle sukkel om te aanvaar dat daar enigiets unieks en spesiaals aan hulle is. Daar is nie sprake van 'n selfbeeld nie. Hulle voel hulle beteken niks. Die toekoms is nie baie belangrik nie.

* Hulle leef in 'n wêreld waarin alles relatief is. Boonop word daar voortdurend (deur ouers en ander meerderes) gesê daar is geen toekoms nie. Dit help ook nie dat hulle hulle in watter rigting ook al bekwaam nie, daar is geen toekoms daarin nie. Daarom bekommer baie hulle nie langer oor die toekoms nie. Al wat belangrik is, is dat hulle nou goed voel.

* Daar bestaan nie so iets soos reg of verkeerd nie. Niks het meer grense nie. Elkeen besluit vir homself of haarself. Jy maak soos jy wil. Hulle doen baie dinge wat meestal geen betekenis het nie. Hulle dra oorbelle in hulle ore en in hulle neuse en op allerhande ander plekke, hulle het die eienaardigste haarstyle en dra die snaakste ('weird') klere. Dit lyk maar net 'cool' en omdat almal dit doen, doen hulle dit ook.

* Omdat identiteit en geborgenheid in die ouerhuis ontbreek, word daar gesoek na baie ander vorme van aanvaarding en intimiteit. Dit het vrye seksuele verkeer (selfs by baie laerskoolkinders) en ander vorme van misbruike tot gevolg. Hulle sukkel egter met blywende verhoudings.

* Straks beteken dit alles dat kinders nie meer veel in die kerk geinteresseerd is nie. Soos die ouers, het die kerk agter geraak en ken nie die probleme waarmee hulle worstel nie. Wanneer die ouers en die kerk nie meer in die prentjie is nie, word God nie meer vertrou nie, en is God nie meer in die prentjie nie.

Die kerk sal moet verlief neem daarmee dat die tyd van die kerkkultuur onherroeplik verby is. Die moderne ingesteldheid van mense lei reeds daartoe en gaan in die toekoms toenemend daartoe lei dat die kerk baie mense gaan verloor (kyk Agenda AKV 1998:195-201 vir die verlies aan lidmate wat die Afrikaanse kerke reeds die afgelope jare lei). Dit is 'n natuurlike proses wat onomkeerbaar verband hou met die moderne 
denkparadigma. Dit het dekades gelede reeds in Europa en die Verenigde State van Amerika gebeur (Steenkamp 1995:617-618). Verder word die kerk vandag gestroop van steunstelsels wat in die verlede vir die kerk sekuriteit gewaarborg het (Van Wyk 1996:157). In die verlede toe die kerkkultuur in Suid-Afrika hoogbloei beleef het, is die kerk deur die regering van die dag, finansiële instellings en dies meer ondersteun en beskerm. Selfs die landswetgewing het die kerk ten goede gekom. Die tyd is vir die kerk in Suid-Afrika verby.

Dit is egter nie net die mens wat deur die kerk bedien word, wat in Suid-Afrika verander het nie. Die hele teologiese klimaat het verander. In die kerk veroorsaak die geweldige verskuiwings wat besig is om in die teologie plaas te vind, onsekerhede en vra dit vir heroriëntering (Oberholzer 1990:870-885). Daar is kennis geneem van die Aufklärung en die liberale teologie, maar die kerk, die kerkvolk en selfs die teologie is nooit in die radikale konsekwensies daarvan daarmee gekonfronteer of selfs behoorlik daaraan blootgestel nie. Daar is sterk klem gelê op die 'regte leer' en daadwerklike kritiese bevraging van die 'regte leer' is uit die midde van die kerk geweer. Vandag is dit nie meer so maklik nie. Die internasionale kritiese teologie het groot invloed en aanhang onder teoloë in Suid-Afrika. Dié kritiese teologie dreig in baie opsigte om die kerk se geloofsbesit en -waarhede te ondermyn en verdag te maak (Kyk Funk 1996: 297-314). Dit is asof die kritiese teologie hier en wêreldwyd veral gerig is teen die kerk, die kerk se belydenisskrifte en geloofsekerhede. In die gees van die tyd en heersende filosofiee oor waarheid word geloofsinhoude bevraagteken, betwyfel en ondermyn. Teen dié agtergrond het die geloofsgemeenskap geloofsekerheid nodig om staande te bly en die oorgange na nuwe paradigmas van bestaan, lewe en kerkwees te verwerk (Van Wyk 1998c:6).

Die tydsgees dwing daarom tans die kerk opnuut om te herbesin oor die kernwaarhede van die evangelie. Die kerk sal opnuut moet besin oor waarby daar gestaan word en waarby daar geval word. Wat is die waarheid en hoe gaan die kerk dit by die premoderne, moderne, en postmoderne mens uitbring? Die verandering van die konteks kan uiteindelik nie die roeping van die kerk verander nie. 'As die eenvoudige evangelie van die gekruisigde en opgestane Christus nie meer genoeg is nie, het die doodsklok begin lui' (Oberholzer 1983:23).

In hierdie besinning sal die kerk deeglik daarmee moet rekening hou dat die kerk sterk en fel weerstand te wagte kan wees. Die staat en die gemeenskap as sodanig is die kerk lank nie meer goedgesind soos dit in die verlede was nie (Dreyer 1996:179ev; Van Wyk 1996:157; Steenkamp 1995:604). Die Hervormde Kerk raak nie alleen verdwerg tussen baie ander kerke nie, maar ook tussen baie ander godsdienste (Van Wyk 1996:157). Die moderne gelowige mens gaan toenemend sy/haar verantwoordelikheid om priester in die geloof te wees, ontken. 


\section{DIE NEDERDUITSCH HERVORMDE KERK OP DIE DRUMPEL VAN DIE EEN EN TWINTIGSTE EEU}

Vir geruime tyd reeds is daar in die Hervormde Kerk kennis geneem van die verskuiwende paradigmas en het besinning onder kerkleiers en teoloe na vore begin tree oor hoe die Hervormde Kerk kan kerk wees in die veranderde tye. In die verband is daar enersyds krities na die kerk gekyk in 'n poging om te besin oor waar die kerk tekort skiet in die kerk se kerkwees. Andersys kom daar stemme na vore wat wys op die positiewe tendense en rigtings in die Nederduitsch Hervormde Kerk se besinning oor kerkwees.

Die volgende kritiese en positiewe sake kom onder andere uit die besinning oor die Hervormde Kerk na vore:

\subsection{Kritiese besinning oor die Hervormde Kerk}

\subsection{1 'n Swak apostolaatsbewussyn}

Die kerk vertoon 'n uiters swak apostolaatsbewussyn. Die Hervormde Kerk het oor baie jare 'n gebrek aan ywer vir sending en evangelisasie. F J van Zyl het in 1962 hieroor al die stem laat hoor. Dit is God wat die kerk in aansyn roep en dit is God wat die kerk in diens neem vir ' $n$ wêreldgerigte sending.

Die God van die Bybel wat Homself in Jesus Christus aan ons bekend gemaak het, is na buite, na die wêreld gerig ... Die wêreld moet weet dat daar so 'n kerk [die Nederduitsch Hervormde Kerk - Van Wyk (jr)] is. En as dit nie die geval is nie, moet die kerk hom ernstig afvra of hy nog kerk is volgens die bedoeling van God ... Is dit nie waar dat ons as kerk meer na binne as na buite lewe nie? Meer op onsself gerig as na buite, na die wêreld? Gaan dit nie miskien vir ons in die eerste en in die laaste instansie net om onsself, ons eie wasdom, ons eie heerlikheid nie?

(Van Zyl 1962:8)

Hierdie vermaning het oor die jare klaarblyklik nie veel indruk gemaak nie, want die swak apostolaatsbewussyn duur voort. 'Die kerk is onwillig en soek verskoning vir bykans 'n eeu lank om nie kragdadig met die geheim van God se liefde na nasies, heidene, die hele wêreld toe te gaan nie' (Van Wyk 1998c:4). Daar is steeds duidelike tekens dat die kerk te veel oorlewingsgerig na binne leef, en te min prinsipieel na buite gerig is (kyk Dreyer 1998:310). Teen hierdie agtergrond is die opmerking van Van Wyk (1998c:3) tog relevant: 'Die kerk maak hier teen die einde van die twintigste eeu 
kennis met die harde realiteit van 'n mensdom wat Jesus Christus bely het en toe afvallig geraak het [en teen die agtergrond van Hebreërs 6:6 nie weer bekeer kan word nie - Van Wyk (jr)]. Ons mislukte evangelisasiepogings is waarskynlik daarvan 'n simptoom.'

\subsection{2 'n Gebrek aan heiligmaking}

Vanuit talle oorde is gewys op die gebrek aan klem op die heiligmaking, die bekering, die wedergeboorte wat daar oor jare in die Hervormde Kerk is. J P Oberholzer het telkens in dié verband die Hervormde Kerk tot bekering en 'n heilige lewe voor God opgeroep (Notule, AKV 1976, 1979; Oberholzer 1990). Die Hervormde Kerk het die etiese aspek van Christenwees verwaarloos (J P Oberholzer, in Van Wyk 1992:31). Hy vra die vraag of ons in die Hervormde Kerk ons netjies afgeweer het teen alle vorme van dwaalleer, maar geweier het om afstand te doen van 'n goddelose lewe? Oor baie jare word 'n slordige, selfs bandelose lewenswyse by baie van die kerk se lidmate en ampsdraers opgemerk. Dieselfde kommer word deur ander ook verwoord: Volgens Van Wyk (1994:1) is die Hervormde Kerk en die lidmate meer bekommerd oor die dogmatiek as oor sy etiek. Bekering, weergeboorte en heiliging het stiefkinders in ons prediking geword. Daar is 'n gebrek aan erns met die heiligmaking en 'n Christelike lewenswandel - ons gebrek aan onderlinge eenheid en liefde, slordige lewenswandel, liefdeloosheid, groepvorming na alle kante toe, 'n voortdurende geskinder wat die lewe van die kerk ontsier, brutale uitdaging van kerklike besluite en kerklike orde waaraan predikante lustig deelneem, selfs die voortou neem (Van Wyk 1998c:4, 1996:158, 161).

Hierdie tendens manifesteer onder andere in swak kerkbesoek by soveel lidmate van die kerk. '[Daar is] nou al waarskynlik baie meer as die helfte van die Kerk se lidmate wat selde en selfs nooit die Woord hoor en sakramente gebruik nie (Van Wyk 1998c:4).

\subsubsection{Tendense van ortodoksie}

Daar kom in die kerk tendense van ortodoksie na vore, van menslike oormoed en selfvoldaanheid. Die kerk en teologie word voor politieke karretjies ingespan - dit blyk onder andere uit sommiges se knaende onrus oor 'n nuwe Bybelvertaling. Ander het 'n houding van alles-bly-soos-dit-is met 'n prinsipiële verset teen alle vernuwing. Die gevaar van selfvoldaanheid en burgerlike godsdiens is inderdaad nie altyd denkbeeldig nie (Van Wyk 1998c:5). 
Die vrees vir 'n volksteologie of burgerlike teologie is al meermale uitgewys. Oberholzer is bevrees dat die kerk al sedert die sestigerjare onder leiding van wyle ds A J G Oosthuizen in 'n hoek gaan staan het waar dié kerk teologies nie tuis is nie. 'n Teologiese staanplek wat baie na aan 'n vorm van burgerlike godsdiens kom. Dit het onder andere na vore gekom in die kerk se verset om Bybels-teologies oor artikel III van die vorige Kerkwet te praat (Oberholzer, in Van Wyk 1992:41). Volgens Dreyer (1996:183) het die Hervormde Kerk, in 'n poging om die evangelieboodskap binne die Afrikanervolk inheems te laat word, juis kontekstuele hermeneutiek benadruk [terwyl die kerk na die ander kant toe in die verlede teen ' $n$ kontekstuele hermeneutiek as die teologie van bevryding en rewolusie in verset was - Van Wyk (jr)]. Die kerk se vereenselwiging met die vryheidstrewe van die Afrikaner se geskiedenis het miskien daartoe gely dat die konteks van die Afrikanervolk (ook politieke strukture) so dominant geword het in die Hervormde Kerk se 'kontekstuele hermeneutiek' dat dit voorwaarde geword het vir die voortbestaan van die kerk (Dreyer 1996:183). Binne dié dampkring word kerk en volk soms op gelyke vlak naas mekaar gestel, asof dit op dieselfde vlak lê en word die gemeenskaplikheid tussen kerk en volk uitgedruk in terme van die gesamentlike stryd teen een of ander vyand wat kerk en volk bedreig (kyk Breytenbach 1998:5). In dié verband word die begrip 'volkskerk' soms ten onregte gebruik as 'n legitimering van die ideologiese beskouing dat die kerk eksklusief tot die Afrikanervolk beperk is en dat lidmaatskap tot lede van die Afrikanervolk beperk is.

\subsubsection{Tendense van liberalisme en modernisme}

Daar kom egter ook in die Hervormde Kerk tendense van liberalisme en modernisme voor. In dié opsig het fasette van die kritiese teologiebeoefening in die kerk 'n negatiewe uitwerking op kerk en geloof (kyk Pont 1994a:5). Die kerk se belydenisskrifte word verdag gemaak. Die indruk van 'n nuwe vorm van vrysinnigheid word gepropageer waar die belydenisskrifte as interessante ou dokumente beskou word wat vir die moderne mens niks meer te sê het nie (Pont 1994b:5). Daar is die neiging tot kritieklose saamloop met politieke ideologieẽ van die dag, baie keer net omdat dit die rigting van die meerderheid is. Dit geld ook waar die kerk slaaf en gevangene gemaak word van die wetenskap en heersende filosofie. Soms raak die wetenskaplike teologiebeoefening ' $n$ doel in sigself, vervreem van die kerk en nie meer primêr in diens van die kerk, die kerklike verkondiging en die opleiding van predikante nie. Kritiese teologiebeoefening word so ver gevoer dat studente verwar en die kerk se kosbaarste geloofsbesit gerelativeer word (Van Wyk 1998c:6). 
[D]aar ... is onrus te bespeur oor wat beskou word as die opkoms van 'n nuwe vorm van modernistiese teologie; ' $n$ teologie wat baie meer akkommoderend wil probeer wees. Daar bestaan onrus en agterdog dat dié teologie nie net sterker wil kennis neem van die tydgees en sy uitdagings nie, maar ook daarby wil aanpas. Daar is kommer oor die verknegting van ons teologie deur tydgees en postmoderne filosofie.

(Die Hervormer 1994:4)

Van Zyl (1994:5) sien in die postmoderne teologie, soos dit onder andere deur sommige kritiese teoloë van die Hervormde Kerk beoefen word, 'n afwyking van die Reformatories-dialektiese denkpatroon wat eie is aan die teologie van die Hervormde Kerk. Van Zyl vermoed (veral ten opsigte van die klem wat die postmoderne op die diesseitige le) 'n analogia entis-dwaling asook 'n verskuiwing in fokus weg van die grootste probleem van die mens, naamlik die sonde, na die oplossing van probleme hier en nou (kyk ook Dreyer 1994:5 wat 'n waarskuwende stem laat hoor oor sekere uitgangspunte van die postmoderne teologie). Oor hierdie saak is daar in die Hervormde Kerk verskil en kom daar selfs groeperings na vore wat volgens sommige dui op verskuiwings in die teologie van die Hervormde Kerk (kyk Dreyer 1995:5, 8; Breytenbach 1995:5; Van der Westhuizen 1995:8).

\subsubsection{Charismatiese tendense}

Daar kom ook in die Hervormde Kerk onrusbarende charismatiese tendense voor. Dit kom veral voor waar predikante en lidmate kennis neem van die destruktiewe gevolge van die modernisme (en die postmodernisme). Om te keer dat die kerk leegloop of lidmate verloor, word halsoorkop allerhande 'gimmics' ingevoer om mense se aandag te probeer trek en hulle emosionele bevrediging te gee. 'Vernuwing in die erediens moet nooit die gebeure vervlak tot die alledaagse nie, dit moet nooit die ontmoeting met God intrek in die sfeer van 'n gemoedelike verhouding nie' (Dreyer 1998:309). Hierdie gevaar van charismatiese tendense in die Hervormde Kerk geld enige en elke poging, openlik of verbloem, om die kerk en die teologie af te trek in allerlei flirtasies en eksperimentering met goedkoop en oppervlakkige sogenaamde charismatiese uitinge en belewinge wat nie Bybelse vernuwing tot gevolg het nie, maar bloot gerig is op die bevrediging van menslike emosies en begeertes (Van Wyk 1998c:5; kyk ook Breytenbach 1997:3). 


\subsubsection{Misplaasde kerkbegrip}

Daar kom 'n misplaasde kerkbegrip by baie lidmate voor (kyk Dreyer 1998:307-308 oor kerkbegrip). Vir baie moderne gelowiges is die kerk niks anders as 'n nuttige gebruiksorganisasie nie. Sulke mense het die houding van: Die kerk is daar om my te bedien. Vir baie is die kerk net ' $n$ 'gebou' of ' $n$ 'struktuur' - daardie 'ding' wat bestaan uit die predikant en die kerkraad en 'n klomp mense en wat instandgehou word deur geld wat die lidmate moet gee. Waar daar so oor die kerk gedink word, het die kerk verword tot 'n menslike instelling wat uit sigself leef en net een doel voor oë het, dit is om finansieel te oorleef. Die finansiële corlewingstryd van baie gemeentes maak inderdaad die verleiding om só oor die kerk te dink, groter. Daar waar lidmate, die predikant of die gemeente so oor die kerk begin dink, is die kerk op die pad na selfvernietiging.

\subsection{Positiewe besinning}

\subsection{1 ' $n$ Bybels-Reformatoriese teologie wat dialekties van aard is}

Dit is duidelik dat die Hervormde Kerk nie net die eie teologie krities analiseer en tipeer nie, maar dit ook as 'n besondere krag vir die kerk en die toekoms van die kerk uitwys. 'In die dialektiese spanning en paradokse van die geloof het die Hervormde Kerk oor die afgelope eeu en baie verder terug sy kerkwees beleef en sy teologie beoefen. Dit is vir die kerk 'n krag en die kerk wil nie daarvan vervreem word nie (Van Wyk 1998c:5).

Die eie teologie van die Hervormde Kerk kan getipeer word as Bybels-Reformatories binne die dialektiese tradisie (Oberholzer 1993:880; Dreyer 1998). 'n BybelsReformatoriese teologie beteken 'n teologie van die Woord. Dit het die Woord van God as die enigste norm en inhoud. Hierdie teologiese basis stempel oor baie jare die kerkbegrip van die Hervormde Kerk. Volgens F J Van Zyl is die Reformatoriese kerk 'n kerk wat die onrus ken. Die kerk besit of beskik nie oor die waarheid nie. Jesus Christus is die weg en die waarheid en die lewe.

Dit is veral die dialektiese teologie wat die eie aard van die Hervormde teologie en kerklike gebruike gestempel het (Dreyer 1998:303-304; Van Wyk 1998b). Daar word in die teologie en geloofsbelewing van lidmate erns gemaak met die gansandersheid van God. God kan nie in menslike proposisies of in die openbaring (die Skrif) of in die geskiedenis vasgevang word nie. Die heiligheid en gansandersheid van God dwing die gelowige tot respek vir God. Daaruit vloei 'n lewe van eerbied en ontsag vir God, nederigheid voor God, en gehoorsaamheid aan God voort (Dreyer 1998:305). Dié teologiese tradisie grens skerp af teen die sogenaamde neo-Calvinistiese opvatting oor die 
rol van die belydenisskrifte in Skrifuitleg. 'n Bybels-Reformatoriese tipering van die Hervormde teologie sluit Lutherse klemtone in. Dit is iets anders as Gereformeerde teologie enersyds en liberale teologie andersyds (Dreyer 1998:304).

Die kerk moet met hierdie Bybels-Reformatoriese basis, binne die idioom van die dialektiese teologie, die eie aard en etos verder uitbou en vryheid gee sodat dié teologie die praktyk van kerkwees met die oog op die toekoms kan bepaal (Dreyer 1998: 311-312). So kan die eg Hervormde teologie die bepaalde gebruike en gewoontes in die erediens, prediking en die lewe van die gemeente stempel. Op hierdie manier word die kerk se identiteit as 'n gemeenskap van gelowiges voor God bevestig.

Voor God is en bly ons bedelaars, eerloses, sondaars. Ons het niks, ons is niks, ons kan niks, ons weet nie wat ons doen nie .... Laat ons tog onthou: Ons is altyd sterker as ons in geloof op God wag as wanneer ons meen ons hét God, beskik oor Hom, besit Hom.

(Van Wyk 1998c:4-5)

Die sterk dialektiese inslag van die Hervormde teologie roep die kerk op om erns te maak met die eskatologie. Daarmee kan die kerk aan die ontnugterde en verwarde mens op die drumpel van die een en twintigste eeu nuwe hoop gee. Daarom lê die kerk in die prediking swaar klem op die eskatologiese verwagting van die komende heil van God (Oberholzer, in Van Wyk 1992:37). In die verband pleit I W C Van Wyk (1996: 501) dat daar in die prediking van die Hervormde Kerk opnuut aandag gegee behoort te word aan die gerig van God en die eindoordeel. Binne die Reformatoriese tradisie was die prediking oor die eindoordeel 'n vanselfsprekendheid aangesien dit deel is van die volle waarheid van die Skrif. Eindoordeel en eskatologiese verwagting gaan immers hand aan hand. Die spel van die teologie word gespeel in die dialektiese spanning tussen tyd en ewigheid (Koekemoer 1992:9).

Daar is die laaste tyd hernude belangstelling in die teologiese groeibodem van die eie aard van die Hervormde teologie (Van Wyk 1998a, 1998b; Dreyer 1998:303; Koekemoer 1996:877vv; Loader 1987, 1996; Oberholzer 1993). Die debat oor die etiese oorsprong van die Hervormde teologie al dan nie, dien as goeie barometer vir 'n eietydse peiling van die kerk se teologie. Hierdie besinning kan die Hervormde Kerk en die beoefening van die teologie net sterker en ryker maak met die oog op die toekoms.

Ander positiewe besinning oor die teologie van die Hervormde Kerk, is dat die kerk gemaklik is met die idee van kritiese teologiebeoefening. Daar bestaan 'n gesonde 
balans tussen ortodoksie en vrysinnigheid. Daar word onderskei tussen die gesag van die Skrif (norma normans) teenoor die belydenisskrifte (norma normata). Die hantering van die belydenisskrifte is bestempel as: vry maar nie bandeloos nie (Oberholzer 1993:874). Die Hervormde teologie is 'n teologie wat vir die Skrif en die uitleg van die Skrif die eerste plek inruim. Dit is 'n gematigde teologie, nooit ekstreem na enige kant toe nie (Oberholzer, in Van Wyk 1992:41). In 'n Herderlike Skrywe in April 1997 word daar volledig gehandel oor die kerk se beskouing oor en hantering van die Skrif in die teologie en kerklike lewe. Die kerk grens sigself bewustelik af teen enige vorm van 'n fundamentalistiese of 'n modernistiese omgaan met die Skrif. Binne die postmoderne teologiese wêreld kom daar opnuut waardering vir mites, metafore en analogiese taalgebruik en die rol daarvan vir die geloofslewe (Van Aarde 1995b; kyk ook Dreyer 1994:5).

Dit blyk dat die Hervormde Kerk verder en in diepte sal moet besin oor die begrip 'volkskerk' wat oor baie jare deel van dié kerk se kerkbegrip uitmaak en tans prominent in die kerk se Kerkorde voorkom (kyk Kerkorde, Ordereël 4:59). Dit is duidelik dat daar nie in die Hervormde Kerk eenstemmigheid is oor wat onder die term 'volkskerk' verstaan word nie. Sommiges sien dit alleen as dat die kerk daarmee wil sê dat die kerk by die blanke Afrikanervolk betrokke wil wees en daartoe beperk is. In dié opsig het volkskerk ' $n$ rasmatige karakter wat ' $n$ tendens van volksteologie weerspieël. Die begrip 'volkskerk' het, so gesien, ook 'n duidelike ideologiese karakter.

Vanuit 'n ander hoek word daar totaal anders oor die begrip 'volkskerk' gepraat. Dit is die volkskerk-begrip soos dit deur onder andere Hoedemaker gestalte in die Nederlandse Hervormde Kerk en Nederduitsch Hervormde Kerk aangeneem het (Van Wyk 1991; Botha 1989:9-28). Hierdie begrip van volkskerk het 'n sterk missionêre karakter (kyk Van Wyk 1994:5). Die kerk leef gerig op die volk en wil al die fasette van die volkslewe kersten. Die grense van kerk en volk val nie noodwendig saam nie. Die kerk rig sigself in die bediening van die Woord tot die hele volk, nie net tot 'n geslote groep wedergeborenes nie (Van Zyl 1989:97; Botha 1989:39). Die grense van daardie volk word nie deur bloed bepaal nie, maar deur die water van die doop.

Die volkskerk se grense is nie die volk nie. Dit is nie 'n volksomsluitende kerk of ' $n$ kerk wat deur kultuur, tradisie of volksgrense bepaal word nie. Die volkskerk waarteen Kuyper in Nederland rede gehad het om te velde te trek, het die onderskeid tussen volkslewe en kerklewe gelykvormig gemaak.

(Van der Westhuizen 1989:51) 
Alhoewel die Hervormde Kerk dus in die bediening van die Woord ten behoewe van 'n bepaalde volk [die Afrikanervolk - Van Wyk (jr)] kies, mag die kerk nie toelaat om deur daardie volk gekaap (Dreyer 1998:308) of eiendom van die volk te word nie (Van der Westhuizen 1989:50).

\subsubsection{Vermoë tot introspeksie en skuldbelydenis}

Die Hervormde Kerk toon die gesonde vermoë om introspeksie te doen oor die wyse hoe die kerk sigself verstaan en die kerk se roeping uitleef. So gaan daar geruime tyd reeds stemme op van persone wat die kerk oproep tot introspeksie en 'n beroep doen dat sodanige introspeksie tot bekering en skuldbelydenis op verskillende vlakke kan lei. Oberholzer (1995:852) vra of die skielike ontwaking van die vraag na die kerk en die wese van die kerk nie alreeds 'n skuldbelydenis is nie. Is dit nie 'n erkenning dat die totale werk van die Hervormde Kerk soos die doenigheid van Marta was, oor baie dinge besorg en bekommerd sonder om aan die voete van die Here te sit en na Hom te luister nie? Die blote feit dat die Hervormde Kerk kerk van die Hervorming is, roep telkens die kerk op om te hervorm en terug te keer na die Bybelse wyse van kerkwees. 'Daar is in die kerk altyd baie wat van tyd tot tyd omvergegooi en uitgedrywe moet word, dinge, gewoontes en gebruike waaraan ons met verloop van tyd so gewoond geraak het, dat ons dikwels nie meer opmerk hoe in stryd hulle soms met die wese van die kerk kan wees nie' (Van Zyl 1962).

Van Wyk (1997:1399-1436) lewer 'n pleidooi dat die debat oor skuldbelydenis oor apartheid binne die kerk aan die gang moet kom (kyk ook W A Dreyer 1998b:2 en Barkhuizen 1998:5). Onlangs het die Hervormde Kerk inderdaad ook besluit om studie te doen oor skuldbelydenis met betrekking tot die kerk se aandeel in apartheid (Notule AKV 1998). Oor dié saak sal daar sekerlik nog baie gepraat word. Dit is duidelik dat die Hervormde Kerk nie deur die tydsgees of deur ideologieë onder druk geplaas gaan word om halsoorkop met dié belangrike en emosionele saak om te gaan nie.

Wat binne 'n geloofsperspektief egter positief is, is dat die kerk die bereidheid het om introspeksie te doen. Ook oor die aard en plek en inhoud van skuldbelydenis van watter aard ook al, sal daar nog baie gepraat moet word. Volgens Van Wyk (1998c:5) '[G]aan die Hervormde Kerk met sy skuld na God toe. Ons bely ons skuld voor Hom en teenoor mekaar. Dit is onmeetlik groot, verskriklik .... Ons staan in die verskriklikste verwonding voor God. Maar nogtans, deur die geloof in Jesus Christus het ons alles, is ons tot alles in staat, weet ons ons is veilig en geborge en behoue.' 


\subsubsection{Positiewe herwaardering van charisma en spiritualiteit}

Daar kom, naas die negatiewe beoordeling van charismatiese tendense wat hierbo vlugtig genoem is, 'n duidelike positiewe herwaardering van die charisma en die werking van die Heilige Gees. Waar die charisma die verkondiging van die vryspraak van sonde wat daar deur Jesus Christus is, verdring en waar net die besig bly met die beoefening van allerlei geestesgawes oorbly, mis die kerk die punt. Uit vrees dárvoor durf die kerk egter nie sigself die rykdom van gawes ontsê wat God deur die Gees beloof en skenk en waardeur werklike vernuwing van die erediens, liturgiese vorme, en die hele kerklike lewe verander en vernuwe word nie (Van Wyk 1998c:5; kyk ook Die Hervormer 1997:1). Daar is 'n groeiende vraag na egte, Bybelse spiritualiteit binne die kerklike gemeenskap. Dreyer (1998:290) pleit ook vir die bestendiging en die uitbouing daarvan binne die eie aard en etos van die Hervormde teologie.

Daar gaan selfs sterk pleidooie op dat die kerk sal moet vernuwe op die talle terreine van kerkwees, veral met betrekking tot die erediens, indien die kerk relevant wil bly en wil oorleef (Geyser 1997; kyk ook Dreyer 1997:2).

\section{GEVOLGTREKKING EN DIE PAD VORENTOE}

Dit blyk dat die kerk van Jesus Christus wêreldwyd in veranderde tye, en midde in 'n veranderde mensdom moet kerkwees. Ook die kerke in Suid-Afrika het hierdie verandering nie vrygespring nie. Trouens, die veranderde en veranderende wêreld en mensdom tref die kerke met onstettende felheid. Besinning oor die roeping van die Nederduitsch Hervormde Kerk in die een en twintigste eeu het reeds begin. Moontlik sal dié kerk se agenda in die toekoms deur onder andere die volgende vrae bepaal word:

\subsection{Waar staan die Hervormde Kerk?}

Waar staan die Hervormde Kerk ten opsigte van die tradisionele wyse van kerkwees wat nie meer te rym is met die postmoderne wyse van teologiebeoefening nie?

- Die gesag van die Skrif, die inspirasieteorie en die kanonbeskouing?

- Die rol van die belydenisskrifte?

- Jesus Christus as die enigste weg tot saligheid?

- Die kerk se profetiese taak?

- Die rol van die opsig en die tug?

In watter paradigma bevind die kerk en teologie hulleself? 


\subsection{Tot wie is die Hervormde Kerk gerig?}

Tot wie is die Hervormde Kerk in die bediening van die Woord gerig? (Dit geld vir die verkondiging aan lidmate én aan buitekerklikes.)

- Tot moderne mense met hulle natuurlike verset teen die gesag van die Skrif en die kerk?

- Of tot postmoderne mense wat die skeptisime oor die kerk en godsdiens deur is en vandag opnuut ' $n$ tipe soeke het na die goddelike, die mistiese, alles wil ondersoek en self wil besluit wat vir hulle sin maak?

- Of selfs nog tot premoderne mense wat alles wat die kerk en die Bybel sê, kritiekloos aanvaar, daarvolgens wil leef en wars is van enige vorm van verandering of vernuwing?

In watter paradigma bevind die kerkvolk hulleself?

Op die vraag in watter paradigma die kerk en teologie hulleself bevind, sal die kerk daarmee moet rekening hou dat die tyd toe tradisionele antwoorde kritiekloos aanvaar is, vir goed verby is. Vir die kerk beteken dit dat die premoderne era vir goed verby is. Wanneer die gesag van die Skrif, die inspirasieteorie, die kanonbeskouing en Jesus Christus as die enigste weg tot saligheid, binne die moderne en postmoderne wyse van teologiebeoefening bevraagteken word, word die fohdamente van die geloof en die kerk bevraagteken. Dit beteken alles is op die spel. Die kerk sal die moderne en postmoderne teologiese vraagstelling nie kan ignoreer nie. Die kerk sal die uitdaging moet aanvaar om alles op die spel te plaas en daarmee opnuut te besin oor die fondament en basiese uitgangspunte van geloof, kerk en teologie.

Op die vraag in watter paradigma die kerkvolk hulleself bevind, ervaar ons 'n dilemma. Sommige dele van die kerkvolk (spesifiek van die Nederduitsch Hervormde Kerk) bevind hulleself binne die premoderne, ander binne die moderne en nog ander binne die postmoderne era. Die kerk, gemeentes en predikante is waarskynlik nie gerat om al drie hierdie groepe mense na behore te bedien nie. Daarom is besinning oor die posisie van die teologiese vraagstelling en oor die posisie van die kerkvolk van die uiterste belang.

As die kerk hierdie vrae duidelik en eerlik kan uitmaak en daarop kan antwoord, kan daar ten opsigte van die premoderne én die moderne én die postmoderne mens op- 
windende verkondigings- en bedieningsmoontlikhede bestaan. Die kerk sal moet ruimte maak om die verskillende mense wat in verskillende paradigmas hulle geloof beleef, te bedien. As die kerk hierdie vrae nie duidelik en eerlik beantwoord nie, sal een van twee dinge gebeur: Ó die kerk sal nie die nuwe moontlikhede en uitdagings raaksien nie en dit onbenut laat verbygaan tot groot skade vir die kerk van Christus (dit gebeur by ortodokse groepe in die kerk). Of die kerk sal rondskarrel om simptome te dokter sonder om die werklike oorsaak van die probleem raak te sien en dít aan te spreek (dit gebeur by diegene wat meen die kerk moet halsoorkop allerhande charismatiese metodes inspan om te keer dat die kerk nie leegloop nie).

\section{Endnotas}

1 Uit die innerlike stryd om die verkondiging van die Bybelse boodskap aan die mense van sy tyd het Barth in 1919 die eerste uitgawe van sy kommentaar op die brief aan die Romeine gepubliseer (Kupisch 1972:46-47). Deur sy hele lewe sou Barth die taak van die teologie sien as toegespits op en in diens van die verkondiging van die Bybelse boodskap: 'Barth heeft er herhaaldelijk en met nadruk op gewezen dat de voornaamste taak van de theologie is te zorgen, dat de dominees vreugde kunnen beleven aan hun preken. Het moet een theologie zijn voor predikanten. Zo heeft Barth zelf altijd graag gepreekt, ook als hoogleraar en bij allerlei voorkomende gelegenheden' (Kupisch 1972:154).

\section{Literatuurverwysings}

Adam, A K M 1995. What is postmodern Biblical criticism? Augsburg: Fortress.

Barkhuizen, J H 1998. Om te bely of nie - 'n ope debat. Die Hervormer, 15 Augustus 1998, bl 5.

Beeld, 1998. Mín vrede op aarde, lui verslag oor 1998-konflik. Beeld, 30 Desember 1998, bl 9.

Bosch, D J 1991. Transforming mission: Paradigm shifts in theology of mission. New York: Orbis Books.

Botha, A 1998. X-generasie. Nuwe Voorligter, Junie 1998, bl 28-29.

Botha, S J 1989. Die volkskerk, in Botha, S J (red), Belydende volkskerk, 1-41. Pretoria: Kital.

Breytenbach, A P B 1997. Charismatiese tendense in die Nederduitsch Hervormde Kerk van Afrika. Die Hervormer, 15 November 1997, bl 3.

Breytenbach, J H 1995. 'n Ontydige verklaring. Die Hervormer, 15 September 1995, bl 5.

1998. Die ideologiese aanslag op kerk en volk. Die Herwormer, 1 Maart 1998, bl 5. 
Die Hervormer 1994. Verskuiwings in ons teologie. 15 Mei 1994, bl 4.

Die Herwormer 1997. Die ekstase van kerkwees. 15 Julie 1997, bl 1.

Dreyer, T F J 1994. Postmoderniteit: 'n Opwindende risiko. Die Hervormer, 1 Maart 1994, bl 5.

1995. Getuienis of strydgeskrif? Die Hervormer, 15 November 1995, bl 5 en 8.

1996. Praktiese kerkwees in die nuwe Suid-Afrika. HTS 52, 179-189.

1998. Spiritualiteit, identiteit en die etos van die Hervormde Kerk. HTS 54, 289-314.

Dreyer, W A 1997. Vernuwing in die Kerk. Die Herwormer, 1 Junie 1998, bl 2.

- 1998b. Om te bely of nie. Die Herwormer, 1 Oktober 1998, bl 1.

Finesse 1998. Waarom Jesus, waarom nét Jesus? Desember 1998, bl 8-10.

Funk, R W. Honest to Jesus: Jesus for a new millenium. San Fransisco: Harper.

Geyser, P A 1997. Kerk in veranderde/veranderende wêreld: Gaan die kerk oorleef?

Voordrag gelewer voor die Predikantevergadering van die Nederduitsch Hervormde Kerk op 10 September 1997.

Hawking, S W 1988. A brief history of time: From the big bang to black holes. New York: Bantam Books.

Herderlike Skrywe aan gemeentes van die Nederduitsch Hervormde Kerk, April 1997.

Küng, H 1988. Theology for the third millenium. New York: Anchor Books.

Küng, H 1992. Credo: The Apostles' Creed explained for today. Münich: Piper Verlag.

Kupisch, K 1972. Karl Barth. Baam: Ten Have.

Koekemoer, J H 1995. Die etos van die Nederduitsch Hervormde Kerk. HTS 51, 876880.

Loader, J A 1987. 'Tertium datur': Oor die etiese waarheidsbegrip. HTS 43, 47-57. - 1996. 'n Hervormde tradisie as heelmiddel. HTS 52, 566-589.

Nederduitsch Hervormde Kerk 1976. Notule van die 58ste Algemene Kerkvergadering. Pretoria: NHKA.

- 1979. Notule van die 59ste Algemene Kerkvergadering. Pretoria: NHKA. 1998. Agenda van die 65ste Algemene Kerkvergadering. Pretoria: NHKA. 1998. Notule vari die 65ste Algemene Kerkvergadering. Pretoria, NHKA.

Oberholzer, J P 1983. Notule van die 60ste Algemene Kerkvergadering. Pretoria: NHKA.

1990. Daar is bekering nodig. Die Hervormer, Februarie 1990, bl 1-2.

- 1993. Die teologiese eieaardigheid van die Nederduitsch Hervormde Kerk:

Vrae en nuanses. HTS 49, 870-886. 
Oberholzer, J P 1995. Die kerk. HTS 51, 851-857.

Pont, A D 1994a. Oor 'n teologie vir die derde millenium. Die Hervormer, 1 Mei 1994, bl 5.

1994b. Kerk en belydenis. Die Herwormer, 1 Oktober 1994, bl 5.

Rossouw, G J 1993. Theology in a postmodern culture: Ten challenges. HTS 49, 894 907.

Steenkamp, L J S 1995. Die kerk onderweg na die een en twintigste eeu: 'n Kritiese besinning oor kerkwees in 'n veranderde konteks in Suid-Afrika. HTS 51, 604 622.

Van Aarde, A G 1995a. Kerk en teologie op pad na die derde millenium: 'n Paradigmatiese verskuiwing van middelmatige aard. HTS 51, 13-38.

1995b. Kerk en teologie op pad na die derde millenium: Die kontekstualisering van die dialektiese teologie in 'n plurale samelewing. HTS 51, 38-59.

- 1996. Die historiese ondersoek na Jesus van Nasaret in perspektief. HTS 52, 476-500.

[1998]. Fatherless in Galilee: The search for Jesus child of God. (Forthooming.)

Van der Westhuizen, H G 1989. Volkskerk as normale kerkbeskouing, in Botha, S J (red), Belydende volkskerk, 48-82. Pretoria: Kital.

1995. Opstellers van Getuienis het geen ander keuse gehad nie. Die Hervormer, 1 Desember 1995, bl 8.

Van Wyk, D J C 1991. P J Hoedemaker: Teoloog en kerkman. 'HTS 47, 1069-1087.

- 1992. J P Oberholzer: 'n Waardering. HTS 48, 17-55.

1994. Stiefkinders in ons prediking. Die Hervormer, 1 Maart 1994, bl 1.

1996. Die roeping van die Kerk in 'n veranderende Suid-Afrika. HTS 52, 147-164.

1998a. Wortels en agtergronde van Hervormde teologie en kerkwees in SuidAfrika. HTS 54, 245-263.

1998b. Die ander opsie: Kohlbrugge, Hoedemaker, Barth. HTS 55/1, 120151.

1998c. Openingsrede tydens die 65ste Algemene Kerkvergadering. Notule 65ste Algemene Kerkvergadering, Argief, Nederduitsch Hervormde Kerk van Arika.

Van Wyk, I W C 1994. Die rol van die Kerk in die nuwe Suid-Afrika. Die Hervormer, 15 Junie 1994, bl 5.

- 1996. Die prediking oor die eindoordeel. HTS 52, 501-531. 
Van Wyk, I W C 1997. Moet die Afrikaanse kerke skuld bely oor apartheid?: Wat leer ons uit die Duitsers se worsteling met skuld? HTS 53, 1399-1436.

Van Zyl, F J 1962. Kerk en wêreld. Die Hervormer, Junie 1962, bl 8.

1989. Volkskerk en vrye kerk, in Botha, S J (red), Belydende volkskerk. Pretoria: Kital. 